\title{
Validation of PSIAC Model for Sediment Yields Estimation in Ungauged Catchments of Tanzania
}

\author{
P. M. Ndomba \\ Department of Water Resources Engineering, University of Dar es Salaam, Dar es Salaam, Tanzania \\ Email: pmndomba2002@yahoo.co.uk
}

Received May 23, 2013; revised June 27, 2013; accepted July 21, 2013

Copyright (C) 2013 P. M. Ndomba. This is an open access article distributed under the Creative Commons Attribution License, which permits unrestricted use, distribution, and reproduction in any medium, provided the original work is properly cited.

\begin{abstract}
The main objective of this paper is to report on preliminary validation results of the newly applied sediment yields estimation model in Tanzania, the Pacific Southwest Inter-Agency Committee (PSIAC). This is a follow-up research on the call to customize simple and/or multi-processes sediment yields estimation models such as PSIAC in the region. The PSIAC approach is based on a sediment yield classification scheme employing individual drainage basin characteristics: surface geology, soils, climate, runoff, topography, ground cover, land use, upland erosion, channel erosion, and sediment transport. In this study, PSIAC model is built from readily available environmental variables sourced from Government ministries/agencies and public domain global spatial data. The sediment classification exercise was verified with field observations. The set up model was then validated by 31 small dams' siltation surveys and previous sedimentation study findings. PSIAC model performance for major part of central Tanzania was good during calibration $(\mathrm{BIAS}=7.88 \%)$ and validation $(\mathrm{BIAS}=18.12 \%)$. Another observation was that uncalibrated model performs fairly well, though performance improves with calibration. The extension of the uncalibrated PSIAC model to 3 selected large basins of Tanzania, with drainage areas size up to $223,000 \mathrm{~km}^{2}$, registered a satisfactory performance in one of them with fair performance in the rest. For large basins, the performance seems to correlate with general ground slope. The higher the slope, the better the performance. It is, however, not apparent from this study on the threshold drainage area and slope requirements for better performance of the model. Notwithstanding, the PSIAC model has improved previous sediment yields estimates based on simple regressive models. Finally, the paper proposes two main further research works: use of high resolution geospatial data and additional validation dams siltation data even beyond the central part of Tanzania, and carries out rigorous study on spatial scale model application limitations.
\end{abstract}

Keywords: Calibration; PSIAC Model; Sediment Yields; Tanzania; Validation

\section{Introduction}

Sediment yield in this paper refers to the amount of sediment exported by a catchment/basin over a period of time, which will eventually enter a lake, reservoir or pond located at the downstream limit of the catchment [1]. It represents total amount of fluvial sediment exported by the catchment tributary to a measurement point (sampling station). Besides, sediment yield is a measure of the response of fluvial system to processes taking place in the drainage basin. Because much of eroded sediment is redeposited before it leaves a catchment, the sediment yield is always less than the upland erosion rates within that same catchment [1]. Available erosionsediment yields estimation tools/models for a catchment vary greatly in complexity from simple regression relationships to complex physics-based distributed simula- tion models [2-4]. Modelling is one of the approaches for estimating catchment sediment yields [5].

Since a decade ago, there have been attempts to apply complex distributed, physics-based erosion-sediment yield models such as Soil and Water Assessment Tool (SWAT) for poor data large catchments in Tanzania [6]. SWAT model uses the original Universal Soil Loss Equation (USLE) and the Modified USLE (MUSLE) to estimate potential soil erosion and sediment yield, respectively [7]. Although good performances have been reported by various researchers in Tanzania and eastern Africa region at large [6], SWAT model is still a data intensive and complex model to be used for planning or operational uses. Besides, uncertainties resulting from multitude of parameters and routing component structure are still pending issues [8]. Therefore, in order to adopt the model for general applications in catchment 
management studies, researchers recommended for SWAT model improvements $[6,8,9]$.

It should further be noted that most of the previous sediment yield estimates studies in Tanzania were catchment specific and resources (data, labour and time) intensive. Moreover, most erosion-sediment yields models such as SWAT are limited to simulating a specific erosion type, e.g., sheet. Hence modelling results in some studies could not be transferred easily to other hydrologic similar catchments $[3,10,11]$. In order to estimate catchment yield, researchers were forced to use uncertain factors such as sediment delivery ratio [12]. The estimation tools used were either complex for operational and wider application or data intensive and could not be validated $[13,14]$. In any case, in Tanzania there is a very scanty knowledge about sedimentation and most of the catchments are poorly gauged $[4,9,15]$. Moreover, Tanzania like many other developing countries, has limited resources in terms of funding and human capital for developing planning tools $[4,11]$.

In a recent study by [4] sediment yields equations were developed for small catchments in Tanzania by regressing small dam sedimentation rates with catchment area. These were the only readily available data. The equations were developed for dry and moderate climate conditions. [4] admitted that the catchment size could not be directly related to erosion process, soil type, and land cover. Such limitations would render the developed sediment yield relationships useful only for preliminary planning purposes or as a rough check. Key limitations of [4]'s research findings include ill-defined study area as the wet climatic zone of Tanzania was not adequately represented; and spatial lumping nature of model representation using catchment area as the only independent variable. It was therefore recommended for future work to incorporate other parameters affecting sediment yield such as landuse, slope and soils.

In this study, a simple and more generic model, Pacific Southwest Inter-Agency Committee (PSIAC) [1,16,17], is used where sediment yield from all erosion types in an appropriate spatial scales is estimated. The PSIAC approach is based on a sediment yield classification scheme employing individual drainage basin characteristics [16, 17]. The characteristics are surface geology, soils, climate, runoff, topography, ground cover, land use, upland erosion, channel erosion and sediment transport. After evaluating individual factors for the whole catchment, the total index is calculated on the basis of summation of the scores of individual factors [16]. The scoring systems are employed to rank areas with specific environmental characteristics [18], thereby estimating their sediment yields.

In comparison with other approaches discussed before this framework demands less data and computational resources. However, it was reiterated by [1] that the framework needs to be validated when applied in areas other than where it was developed. Despite the fact that PSIAC model has been tested elsewhere [19-21], to the best of author understanding, none is known on its performance on Tanzania ungauged catchments.

Therefore, the main objective of this paper is to report on preliminary validation results of the newly applied sediment yield estimation model, PSIAC, in Tanzania. This is a follow up research on the call to customize simple and/or multi-processes sediment estimation models such as PSIAC in the region [4]. This research is linked to other initiatives in Tanzania such as those of sedimentology studies in 3 large basins of Tanzania, namely Lake Nyasa, Lake Tanganyika, and Pangani.

\section{Material and Methods}

\subsection{Study Area Description}

This study is about validating the performance of the multi-factors model, PSIAC, which on statistical grounds; it requires higher number of spatially distributed observations than the model factors. The study considers erosion types mainly resulting from hydrospheric forces (i.e., rainfall, runoff and streamflows). Therefore, the study area was presupposed to cover various climatic regions. Following suit, the study area for model validation was dictated by the availability of small dams with siltation data and various climatic conditions representation in Tanzania (Figures 1-3).

Tanzania is located in eastern part of Africa continent and just South of the equator (Figure 1). It lies between the area of the Great Lakes-Victoria (northern), Tanganyika (western) and Nyasa (South-West) - and bordered by the Indian Ocean on the East. Tanzania contains a total area of $945,087 \mathrm{~km}^{2}$ including $59,050 \mathrm{~km}^{2}$ of the inland water. Tanzania has a tropical climate with three (3) major climatic zones viz., wet, moderate and dry (Figure 2). Moderate climatic zone receives rainfall for 1 to 3 months in a year. The administrative regions which fall under this climatic zone are Mwanza, Mara, Iringa, Tabora, Bukoba, Lindi, Morogoro, Kilimanjaro, Tanga and Arusha. In the highlands, temperatures range between $10^{\circ} \mathrm{C}$ and $20^{\circ} \mathrm{C}$ during cold and hot seasons, respectively. The rest of the country has temperatures rarely falling lower than $20^{\circ} \mathrm{C}$. The hottest period extends between November and February $\left(25^{\circ} \mathrm{C}-31^{\circ} \mathrm{C}\right)$ while the coldest period occurs between May and August $\left(15^{\circ} \mathrm{C}\right.$ $20^{\circ} \mathrm{C}$ ). Tanzania has two major rainfall regimes. One is unimodal (December-April) and the other is bimodal (October-December, OND; and March-May, MAM). The former is experienced in southern, South-West, central and western parts of the country, and the latter is found on the North and northern coastal areas. In the bimodal 


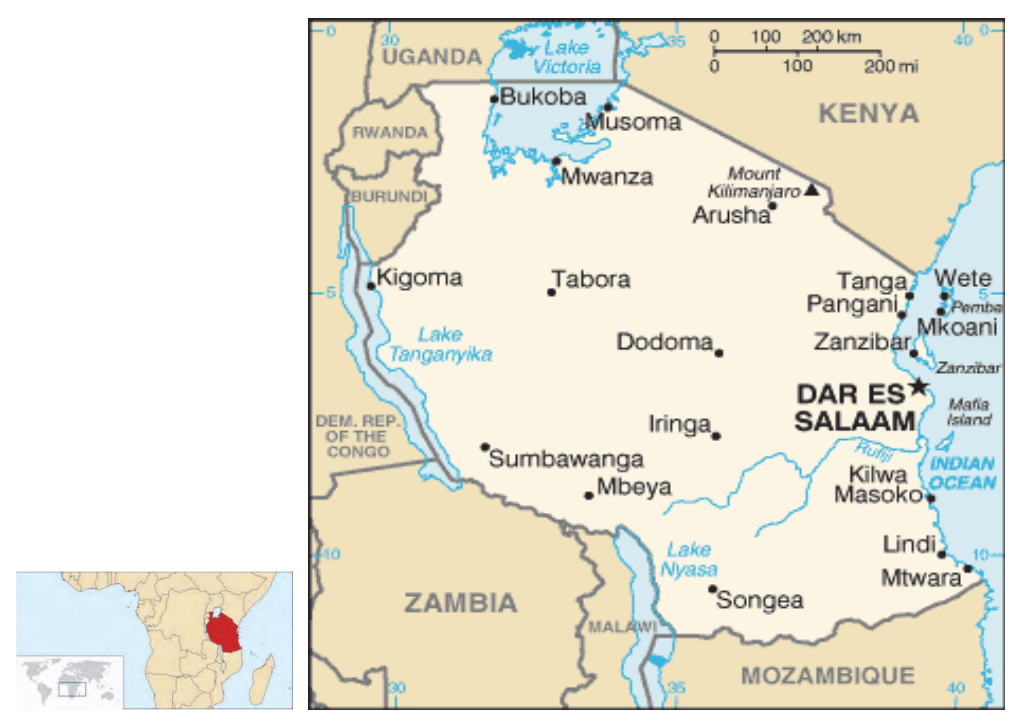

Figure 1. Location map of Tanzania.

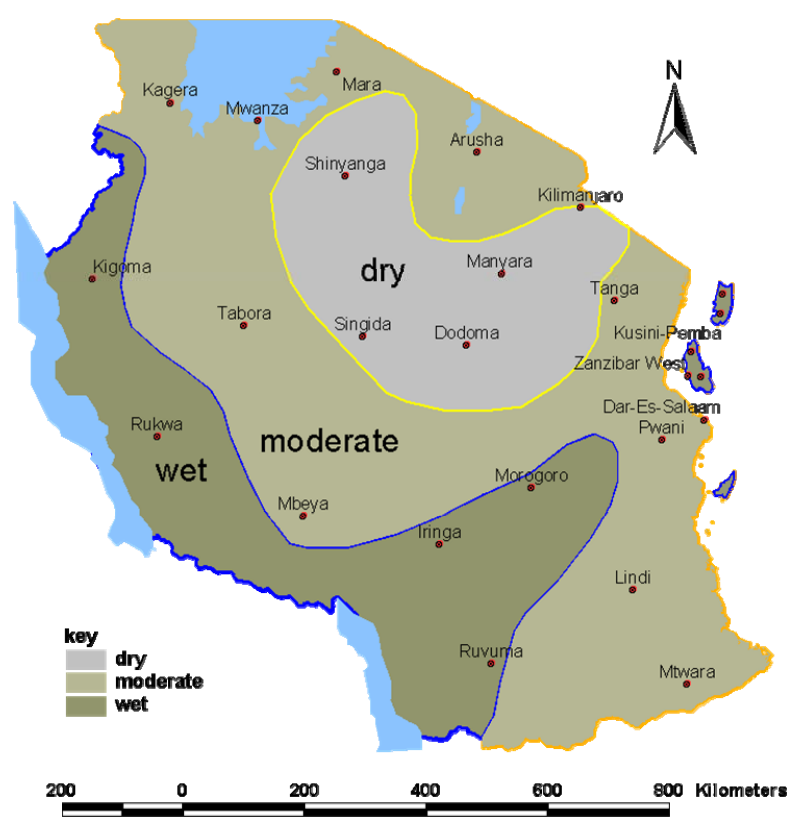

Figure 2. Map showing climatic zones of Tanzania [26].

regime the March-May rains are referred to as the long rains or "Masika", whereas the October-December rains are generally known as short rains or "Vuli".

The study area, where majority of dam siltation data could be readily obtained, is the central part of Tanzania (Figure 3). It is mainly covered by a large plateau [22]. The plateau has a mean elevation of about 1100 masl, and consists of several precambrian terrains that have experienced Cenozoic extension [22]. The southern half of this plateau is grassland within the eastern Miombo woodlands ecoregion. In the North the plateau is arable land and includes the national capital, Dodoma (Figure 1). Besides, the study area falls within the administrative

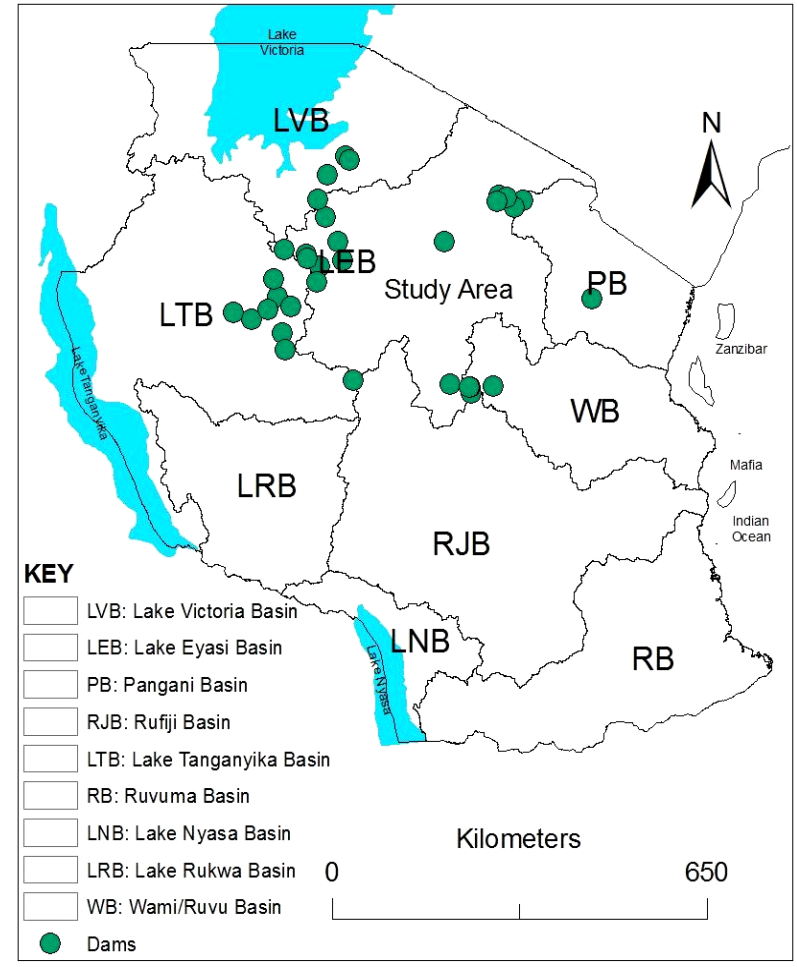

NB: The dots represent positions of the dams that were used in this study.

Figure 3. Location map of the study area, central part of Tanzania with the spatial extent defined by small dams used in this study plus basins of Tanzania.

regions of Tabora, Singida, Shinyanga, Arusha and Dodoma.

\subsection{Data and Data Analysis}

\subsubsection{Data Types and Sources}

Three major types of data used for model building and 
validation include environmental variables, dam siltation and published sedimentation data as reported in $[5,23,24]$. Environmental variables such as geological and lithological map with a scale of 1:250,000 of Tanzania [25] were used to extract surface geological features. The soil features were determined based on soil erodibility factor (USLE_K) from soil map of Africa. Climate was classified based on [26] and mean annual rainfall map [27]. In SUA's study the mean annual rainfall (mm/yr.) was estimated based on available data from 1971 to 2000 . Runoff factor was based and extracted from the Southern Africa average annual runoff map [28]. Topographic factor was determined based on average percentage of slope steepness. The average slope steepness was generated from Digital Elevation Model (DEM) of $90 \mathrm{~m}$ resolution. The ground cover was evaluated based on fractional cover (FC). The land use was estimated based on economic activities on the land such as agriculture, grazing, deforestation, small scale mining, buildings or roads. The upland erosion and channel erosion information were obtained from the Global Assessment of Soil Degradation (GLASOD: [29]) and runoff maps.

Data for fifty three (53) dams were collected with attributes including name of the dam, full supply level of the dam, capacity of the dam at full supply level, year of construction, accumulated sediment volume in the dam, year of dam survey, volumentric rate of sediment accumulation in the dam (sediment fill per year), geographic position, and catchment area. The dams were built for various purposes, including but not limited to irrigation, domestic water supply, livestock watering, flood control and fishing.

\subsubsection{Data Analysis}

The statistics and physical characteristics of the selected water supply-irrigation small dams in Tanzania are presented in Table 1. It should be noted, however, that twenty two (22) dams were not included in the final analysis for two reasons: either their siltation data were considered outliers or dams' geographical positions could not be readily obtained.

A geographic position of the dam was crucial as it was used in this study to extract environmental variables from geospatial data/maps required for PSIAC model building. Therefore, only 31 dams with sediment yield data as presented in Table 2 were used for further analysis. Specific sediment yield presented in the last column of Table 2 was derived as the ratio of sediment yield to dam catchment area.

As mentioned earlier under data types subsection the basic data for PSIAC model factor derivation were obtained from topographic maps, geological, soil, land use, ground cover, runoff, climate (mean annual rainfall), Normalized Difference Vegetation Index map (NDVI)NOAA, and GLASOD maps. The data were used to generate spatial data layers and to evaluate the sediment factors based on PSIAC concept for the sediment model determination under GIS environment. Each river characteristic was scaled based on PSIAC sediment yield factor rating sheet $[16,17]$. All factors characterized by PSIAC model approach were described in a way of acquiring the PSIAC-Indices for each catchment. The PSIAC-Indices for the 31 dams selected were obtained through preparation, classification and assignment of weights according to PSIAC model building procedures. As illustrated in Table 3. Six (6) out of nine (9) river characteristics (surface geology, soil, climate, runoff, land use, and channel erosion) were acquired through interpolating the rating limits [17]. The interpolation was conducted based on corresponding characteristics of the spatial maps.

The surface geological map of Tanganyika was used to extract surface geological features. For instance, the volcanic and metamorphic rocks classified as massive and hard rocks were assigned a low rating limit. Moderate weathered and fractured rock, and ground surface of sand, silt, related with mudstones and siltstones were assigned a rating limit from 0 to 10 (Table 3 ).

The soil features were determined based on soil

Table 1. Physical characteristics of the selected water supply-irrigation small dams in Tanzania.

\begin{tabular}{ccc}
\hline Statistics & Reservoir Storage/Capacity $\left(\mathrm{m}^{3}\right)$ & Dam Catchment Area $\left(\mathrm{km}^{2}\right)$ \\
\hline Number of Dams, $\mathrm{n}$ & 609 & 53 \\
Lowest & 500 & 267.00 \\
Maximum & $40,722,000$ & 41.66 \\
Mean & 599990.9 & 59.62 \\
Standard Deviation (STD) & 2516026.45 & 143.12 \\
Coefficient of Variation, CV, (\%) & 419.3 & 8.19 \\
Standard Error of the Mean (SEM) & 101954.5 & \\
\hline
\end{tabular}


Table 2. (a) Dams' data used for model validation; (b) Dams' data used for model validation.

(a)

\begin{tabular}{|c|c|c|c|c|c|}
\hline \multirow{2}{*}{ SN } & \multirow{2}{*}{ Name of Dam } & \multicolumn{2}{|c|}{ Geographic Position } & \multirow{2}{*}{$\begin{array}{c}\text { Dam Catchment Area } \\
\left(\mathbf{k m}^{2}\right)\end{array}$} & \multirow{2}{*}{$\begin{array}{c}\text { Specific } \\
\text { Sediment Yield }\left(\mathrm{t} / \mathrm{km}^{2} / \mathrm{yr}\right)\end{array}$} \\
\hline & & Latitude (deg.) & Longitude (deg.) & & \\
\hline 1 & Matumbulu & -6.300 & 35.767 & 15 & 183.3 \\
\hline 2 & Tura & -4.200 & 33.200 & 105 & 68.6 \\
\hline 3 & Kakola-Tabora & -4.833 & 32.767 & 3.7 & 443.2 \\
\hline 4 & Kisongo & -3.370 & 36.570 & 9.3 & 264.1 \\
\hline 5 & Igingwa & -5.380 & 32.830 & 10 & 280.0 \\
\hline 6 & Ibadakuli & -3.633 & 33.500 & 10 & 294.4 \\
\hline 7 & Bashay & -4.000 & 35.350 & 78 & 218.5 \\
\hline 8 & Bubiki & -3.370 & 33.380 & 11 & 288.0 \\
\hline 9 & Buigiri & -6.183 & 36.117 & 10.3 & 273.8 \\
\hline 10 & Ulaya & -4.380 & 33.420 & 8.3 & 245.5 \\
\hline 11 & Usoke & -5.170 & 32.350 & 1.9 & 473.7 \\
\hline 12 & Kikola-Dodoma & -6.167 & 35.433 & 3.7 & 443.7 \\
\hline 13 & Malya & -2.983 & 33.533 & 15 & 268.1 \\
\hline
\end{tabular}

(b)

\begin{tabular}{|c|c|c|c|c|c|}
\hline \multirow{2}{*}{$\begin{array}{l}\text { SN } \\
14\end{array}$} & \multirow{2}{*}{$\frac{\text { Name of Dam }}{\text { Losira (Losirwa) }}$} & \multicolumn{2}{|c|}{ Geographic Position } & \multirow{2}{*}{$\begin{array}{c}\begin{array}{c}\text { Dam Catchment } \\
\text { Area }\left(\mathbf{k m}^{2}\right)\end{array} \\
87\end{array}$} & \multirow{2}{*}{$\begin{array}{c}\text { Specific } \\
\left.\text { Sediment Yield (t/ } \mathbf{k m}^{2} / \mathbf{y r}\right) \\
639.5\end{array}$} \\
\hline & & -4.867 & 37.650 & & \\
\hline 15 & Msalatu & -6.200 & 35.750 & 8.5 & 288.4 \\
\hline 16 & Imagi & -6.200 & 35.733 & 2.2 & 863.6 \\
\hline 17 & Mbola & -5.023 & 32.610 & 6.4 & 390.6 \\
\hline 18 & Mambali & -4.572 & 32.699 & 2.7 & 723.9 \\
\hline 19 & Nguliati & -2.700 & 33.817 & 12 & 265.5 \\
\hline 20 & Meserani & -3.483 & 36.433 & 56 & 628.9 \\
\hline 21 & Lepurko-Hills & -3.300 & 36.200 & 65 & 571.0 \\
\hline 22 & Malolo & -4.120 & 32.870 & 15 & 198.0 \\
\hline 23 & Uchama & -4.227 & 33.192 & 97.5 & 219.0 \\
\hline 24 & Bulenya Hills & -4.280 & 33.770 & 194 & 58.5 \\
\hline 25 & Urambo & -5.070 & 32.070 & 38 & 181.1 \\
\hline 26 & Sakwe & -2.770 & 33.880 & 9 & 301.6 \\
\hline 27 & Magulia & -4.617 & 33.367 & 15.8 & 212.2 \\
\hline 28 & Utatya & -5.633 & 32.883 & 4 & 290.8 \\
\hline 29 & Manolea & -4.983 & 32.967 & 3 & 466.7 \\
\hline 30 & Ngamuriaki & -3.337 & 36.314 & 76 & 493.9 \\
\hline 31 & Essimingor & -3.385 & 36.163 & 94 & 1221.3 \\
\hline
\end{tabular}


Table 3. Surface geology factors and assigned rating limits.

\begin{tabular}{cc}
\hline Surface Geology Characteristics & Rating Limits \\
\hline Massive, Hard formation including un-metamorphosed gabbroic, Granite and granodiorites & $0-1$ \\
Bended ironstone, meta-volcanics, chlorite schist, pseudo-porphyry & $1-3$ \\
Rocks of medium hardness, moderately weathered or fractured; & $3-5$ \\
Continental: conglomerate, sandstone, red and grey mudstone - siltstone, clay; carbonaceous shale and coal & $5-7$ \\
Marine shales related mudstone and silt stones; Alluvial, lacustrine, fluvial, terrestrial and marine areas & $7-10$ \\
\hline
\end{tabular}

erodibility factor (USLE_K) derived from FAO soil map of Africa. The map was acquired from global data sets available online. The study area soil erodibility factor values range from 0 to 0.426 . The USLE $\mathrm{K}$ for the soil rich in clays and organic materials defines a lower limit because such soils have low sediment generation potential. The soil characterized as silts, sand, and fine textures has higher USLE_K, hence, is defined as upper rating limit. The USLE_K was interpolated and resulted into the rating limits between 0 and 10 .

Climate in this study is defined by range of mean annual rainfall amount. Rainfall is considered as the major contributor to soil erosion due to raindrop splashing impact and sediment entrainment [30]. The mean annual rainfall amount in $\mathrm{mm} / \mathrm{yr}$ was estimated based on 30 years period of available data from 1971 to 2000. The mean annual rainfall ranging from 0 to 2400 $\mathrm{mm} / \mathrm{yr}$ was assigned the rating limits between 0 and 10 .

Based on mean annual runoff map for the study area, the extracted minimum and maximum mean annual runoff are 17 and $1250 \mathrm{~mm} / \mathrm{yr}$, respectively, with a mean of $531 \mathrm{~mm} / \mathrm{yr}$ and $\mathrm{CV}$ of $62.4 \%$. The corresponding rating limits are 0 and 10 .

The rating limits for the remaining three PSIAC model environmental variables inputs (topography, ground cover, and upland erosion) were adopted from [17].

Topographic factor was determined based on average percentage of ground slope steepness. The Digital Elevation Model (DEM) of Africa acquired from global data sets that are available in USGS website was used to analyse an average percentage slope within the catchment.

Ground Cover factor was derived from vegetation, litter and rocks. The ground cover was evaluated based on fractional cover (FC) Equation, $\mathrm{FC}=0.114+1.284 \times$ NDVI, as adopted from [31]. The global datasets for NDVI map was obtained from [32]. The percentage of fractional cover was used to assign rating limits. The limits ranged from -10 to 10 .

The land use was classified based on the status of soil degradation (GLASOD). The latter is expressed as the severity of the process. The severity is characterized by degree in which the soil is degraded and by relative extent of degraded area within delineated physiographic unit. The rating limits of -10 and 10 correspond to severity levels of $0 \%$ and $100 \%$, respectively.

The upland erosion was derived from both GLASOD and runoff maps. The severity of degradation is measured by the extent of rill and gully formation or mass movement. Potential upland erosion as represented/ measured by Severity was weighted/factored by runoff in order to infer upland erosion characteristics as presented in Table 4. It should be noted that both severity and runoff were percentile classified.

Channel erosion was also derived from the GLASOD and annual runoff maps as for upland erosion factor. In this case a severity of sheet erosion was used. Potential channel erosion as represented/measured by Severity was weighted/ factored by runoff in order to infer channel physical characteristics.

The total PSIAC index values are obtained by summation of evaluated individual factor indices for each catchment (Table 5). The PSIAC index combines the PSIAC parameters as determinant factors to estimate specific sediment yield (SSY) for each catchment. Each catchment contained only one dam at the outlet. Classification of sediment yield and rating under PSIAC model framework is presented in Table 6.

\subsection{Development of a Sediment Yield Regression Model Based on PSIAC Concept}

Considering scanty data from 31 dams with siltation data (Tables 2(a) and (b)), for validation purpose it was considered necessary to minimize the number of calibration parameters for the intended model. As recommended by [33] at least 10 to 20 times as many observations (cases, respondents) as variables, should be used for stable estimates of a regression line and replicability of results. In this case for PSIAC model with 9 determinant factors, a minimum of 90 observations would have been required for this analysis to arrive at meaningful confidence. In this context two types of regression model forms with a maximum of two model parameters were explored as candidates. These are straight line and power functions (Equations (1) and (2)). 
Table 4. Upland erosion rating limits.

\begin{tabular}{cc}
\hline Upland Erosion Characteristics & Percentage (\%) \\
\hline More than $50 \%$ of the area characterized by rill and gully or landslide erosion & $50-30$ \\
About $25 \%$ of the area characterized by rill and gully or landslide erosion; & $25-13$ \\
Wind erosion with deposition in stream channels & $30-25$ \\
No apparent signs of erosion & $13-10$ \\
\hline
\end{tabular}

Table 5. Factors indices and PSIAC-Index for 31 Dams.

\begin{tabular}{|c|c|c|c|c|c|c|c|c|c|c|c|}
\hline \multirow{2}{*}{ SN } & \multirow{2}{*}{ Catchment } & \multicolumn{9}{|c|}{ Environmental Parameters } & \multirow{2}{*}{ Total PSIAC-Index } \\
\hline & & SG & s & CR & $\mathbf{R}$ & $\mathbf{T}$ & GC & $\mathbf{L U}$ & UE & $\mathbf{C E}$ & \\
\hline 1 & Bashay & 0 & 0 & 4 & 5 & 0 & 5 & 4 & 7 & 10 & 35 \\
\hline 2 & Bubiki & 5 & 1 & 5 & 5 & 0 & -1 & 4 & 5 & 8.5 & 32.5 \\
\hline 3 & Buigiri & 0 & 4 & 0 & 0 & 0 & 5 & 10 & 8 & 11 & 38 \\
\hline 4 & Bulenya & 3 & 0 & 4 & 5 & 0 & -1 & 4 & 5 & 5 & 25 \\
\hline 5 & Essimingor & 0 & 0 & 5 & 5 & 0 & 5 & 6 & 9 & 14 & 44 \\
\hline 6 & Ibadakuli & 3 & 0 & 5 & 5 & 0 & 8 & 4 & 5 & 8 & 38 \\
\hline 7 & Igingwa & 0 & 4 & 5 & 1 & 0 & -1 & 7 & 8 & 14 & 38 \\
\hline 8 & Imagi & 0 & 4 & 2 & 0 & 0 & 5 & 8 & 10 & 15 & 44 \\
\hline 9 & Kakola & 0 & 4 & 5 & 1 & 0 & -1 & 7 & 8 & 13 & 37 \\
\hline 10 & Kikola & 0 & 4 & 0 & 0 & 0 & 8 & 7 & 6 & 13 & 38 \\
\hline 11 & Kisongo & 0 & 0 & 3 & 5 & 0 & 10 & 5 & 3 & 9 & 35 \\
\hline 12 & Losira & 0 & 2 & 3 & 1 & 0 & 5 & 10 & 8 & 13 & 42 \\
\hline 13 & Luperko & 0 & 0 & 2 & 5 & 2 & 8 & 5 & 7.5 & 15 & 44.5 \\
\hline 14 & Magulia & 0 & 5 & 5 & 1 & 0 & 5 & 5 & 4 & 10 & 35 \\
\hline 15 & Malolo & 0 & 1 & 5 & 4 & 0 & -2 & 4 & 7 & 15 & 34 \\
\hline 16 & Malya & 4 & 2 & 5 & 3 & 0 & 10 & 4 & 4 & 5 & 37 \\
\hline 17 & Mambali & 0 & 4 & 5 & 5 & 0 & -1 & 6 & 10 & 12 & 41 \\
\hline 18 & Manolea & 0 & 4 & 5 & 1 & 0 & -1 & 7 & 8 & 13 & 37 \\
\hline 19 & Matumbulu & 1 & 4 & 0 & 0 & 0 & 10 & 7 & 7 & 5 & 34 \\
\hline 20 & Mbola & 4 & 2 & 5 & 4 & 0 & 5 & 4 & 6 & 8 & 38 \\
\hline 21 & Meserani & 0 & 0 & 3 & 5 & 0 & 5 & 5 & 8 & 15 & 41 \\
\hline 22 & Msalatu & 0 & 4 & 1 & 0 & 0 & 8 & 10 & 8 & 10 & 41 \\
\hline 23 & Ngamuriaki & 0 & 0 & 5 & 5 & 0 & -6 & 5 & 10 & 20 & 39 \\
\hline 24 & Nguliati & 0 & 0 & 5 & 5 & 0 & 5 & 4 & 7 & 10 & 36 \\
\hline 25 & Sakwe & 0 & 0 & 5 & 3 & 0 & 5 & 5 & 8 & 9 & 35 \\
\hline 26 & Tura & 1 & 5 & 5 & 1 & 0 & -2 & 5 & 5 & 12 & 32 \\
\hline 27 & Uchama & 0 & 0 & 5 & 1 & 0 & -1 & 6 & 9 & 15 & 35 \\
\hline 28 & Ulaya & 0 & 3 & 5 & 2 & 0 & -2 & 6 & 7 & 14 & 35 \\
\hline 29 & Urambo & 0 & 5 & 5 & 5 & 0 & -2 & 5 & 5 & 10 & 33 \\
\hline 30 & Usoke & 0 & 4 & 5 & 5 & 0 & -4 & 5 & 8 & 15 & 38 \\
\hline 31 & Utatya & 0 & 4 & 5 & 1 & 0 & 5 & 7 & 7 & 12 & 41 \\
\hline
\end{tabular}

Note: $\mathrm{SG}=$ Surface Geology; $\mathrm{S}=$ Soils; $\mathrm{CR}=$ Climate; $\mathrm{R}=$ Runoff; $\mathrm{T}=$ Topography; $\mathrm{GC}=$ Ground Cover; $\mathrm{LU}=\mathrm{Land}$ use; $\mathrm{UE}=\mathrm{Upland}$ Erosion; $\mathrm{CE}=\mathrm{Channel}$ erosion. 
Table 6. Classification of sediment yield and rating as adopted from [16].

\begin{tabular}{ccc}
\hline Class & Rating Based PSIAC Index () & Sediment Yield (mm/yr) \\
\hline 1 & $>100$ & $>1.5$ \\
2 & $75-100$ & $0.5-1.5$ \\
3 & $50-75$ & $0.25-0.5$ \\
4 & $25-50$ & $0.1-0.25$ \\
5 & $<25$ & $<0.1$ \\
\hline
\end{tabular}

$$
Y_{i}=\beta_{0}+\beta_{1} X_{i}+\varepsilon_{i}, i=1,2 \ldots, n
$$

where $n$ is number of dam catchments, $X_{i}$ is independent variable (PSIAC-Index or PSIAC based sediment yield estimate, PSIAC $\mathrm{SSY}_{\mathrm{SS}}$, $Y_{i}$ is dependent variable (measured sediment yield as estimated from dam siltation data, $\mathrm{SSY}_{\mathrm{dam}}$ and two parameters, $\beta_{0}$ and $\left.\beta_{1}\right), \varepsilon_{i}$ is an error term, and the subscript $i$ indices a particular catchment.

$$
Y_{i}=\alpha X_{i}^{\beta}
$$

where $\alpha$ and $\beta$ are coefficient and exponent of the equation, respectively. The regression model for the linear function is done directly by using $Y_{i}$ and $X_{i}$ values, while for the regression of the power function the logarithmic function is applied to the Equation (2) to obtain $\alpha$ and $\beta$ coefficients but both are regressed (Equation (3)). The powerful relationship is confirmed when its correlation is high on statistical grounds.

$$
\log Y_{i}=\log \alpha+\beta \log X_{i}
$$

The development of these equations was done under Excel spreadsheet environment using regression analysis and Analysis of variance (ANOVA) tool packs. In principal regression tool pack was first used to fit models to data, and then ANOVA was used to make sense of the fitted models, and to test hypotheses about the coefficients.

\subsection{Sediment Yield Model Performance Evaluation}

The dams data sample size was divided into two sets for model calibration (70\%) and validation (30\%). Model validation involves running a model using input parameters measured or determined during the calibration process. Model validation exercise was meant to demonstrate that the fitted model is capable of making accurate estimation using an independent data set. The approach was considered as a superior and a more dependable method for measuring residuals.

Model evaluation techniques included at least one dimensionless statistic Nash and Sutcliffe efficiency (NSE), one absolute error index statistics (RMSE), and other statistical information such as the standard deviation of measured data. NSE could range from $-\infty$ to 1 . Essentially, the closer the model efficiency is to 1 , the more accurate the model is. NSE values $\leq 0.5$ are considered unsatisfactory [34], and NSE values $\leq 0$ indicate the mean observed value is a better predictor than the predicted values. Besides, NSE indicates how well the plot of observed versus predicted data fits the 1:1 line. Based on [35] the NSE coefficient is expressed in Equation (4). However, in the later section of this paper the NSE is presented in percent.

$$
\mathrm{NSE}=1-\left[\frac{\sum N_{i=1}\left(m_{i}-P_{i}\right)^{2}}{\sum N_{i=1}\left(m_{i}-m\right)^{2}}\right]
$$

where $N=$ number of dam catchments, $m_{i}=$ measured sediment yields $\left(\mathrm{SSY}_{\mathrm{dam}}\right), \mathrm{m}=$ mean measured sediment yields, and $P_{i}=$ predicted sediment yield.

Optimization of RMSE during model calibration may give a small error variance. The model was also evaluated through observation standard deviation ratio (RSR) and percent bias (PBIAS). RSR is the ratio of the RMSE and standard deviation of the measured data, as calculated in Equation (5).

$$
\mathrm{RSR}=\frac{\mathrm{RMSE}}{\text { STDEVobs }} \frac{\left[\sum N_{i=1}\left(m_{i}-P_{i}\right)^{2}\right]}{\left[\sum N_{i=1}\left(m_{i}-m\right)^{2}\right]}
$$

RSR ranges from 0 to a large positive value. Lower values indicate better model performance, with a value of 0 being optimal. It should be noted that in practice the optimal performance is rarely obtained. PBIAS measures the average tendency of the predicted data derived from the model to be larger or smaller than measured data. The optimal value of PBIAS is 0.0 , with low-magnitude values indicating accurate model prediction/simulation. Positive values indicate model underestimation bias, and negative values indicate model overestimation bias. PBIAS was calculated using Equation (6).

$$
\text { PBIAS }=\left[\frac{\sum\left(m_{i}-P_{i}\right)}{\sum m_{i}}\right]
$$

Prediction performance through PBIAS was classified 
based on [34] approach as follows: for PBIAS $<10 \%$ (very good); $10 \%-15 \%$ (Good); $15 \%$ - 25\% (satisfactory) and $>25 \%$ (unsatisfactory) for the calibration and validation.

In some applications in this study, where validation data are limited, Relative Error measure, RE, was used to evaluate model performance. In such cases good performance is confirmed when RE in percent is less than $20 \%$. This threshold is considered satisfactory for most of engineering practices.

$$
\operatorname{RE}(\%)=\left|\left(\frac{\text { Actual }- \text { Estimated }}{\text { Actual }}\right)\right| 100
$$

\section{Results and Discussions}

\subsection{Evaluated PSIAC Model Performance}

As a first step of PSIAC model development, especially as it was applied for the first time in Tanzania, there was a need to investigate how the measured determinant factors correlate with the measured sediment data. As depicted in Figure 4 it was observed that measured sediment yields $\left(\mathrm{SSY}_{\mathrm{dam}}\right)$ correlate with PSIAC indices (PSIAC_Index) and PSIAC based sediment yield estimates (PSIAC SSY) with coefficient of determination $\left(r^{2}\right)$ of 0.61 and 0.66 , respectively. You will note that both PSIAC_index and PSIAC_SSY as independent variables and as presented into two separate horizontal axes (primary-lower and secondary-upper) share one vertical axis of measured sediment yields $\left(\mathrm{SSY}_{\mathrm{dam}}\right)$. Such presentation was intended to separate the two data sets for clarity purposes only. Otherwise, the data points would have clustered together. According to Student's t-distribution with 29 degree of freedom, the read out table value at $5 \%$ level of significance, $\mathrm{t}_{0.05}$ is 2.045 . As the computed $t$ of 6.73 is greater than the table value, thus the correlation is considered significant [36]. As other researchers put it, typically $\mathrm{r}^{2}$ values greater than 0.5 are acceptable and warrant further analysis of the data [37].

This analysis suggests also that a strong correlation between measured and simulated sediment yield is confirmed. Besides, the analysis allowed development of regressive sediment yield models using either PSIAC_Index or PSIAC_SSY as determinant factors, with the latter factor registering much stronger correlation. As explained in the methodology section above and as supported by correlation analysis, for further analysis, model calibration and validation, the estimated sediment yield (PSIAC_SSY) was used as determinant factor. Out of 31 dams 22 randomly selected were used for model calibration (Figure 5). Based on both qualitative and quantitative analyses of scatter plot (Figure 5), the power function was chosen as the best regression model for this

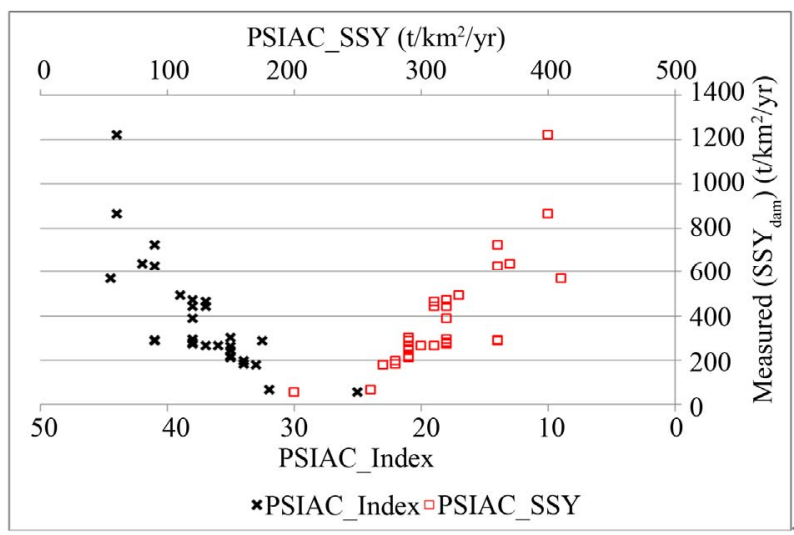

Figure 4. Scatter diagram of 31 data points between measured (SSY $_{\text {dam }}$ ) and uncalibrated PSIAC based Sediment yields (PSIAC_SSY) and PSIAC indices (PSIAC_Index).

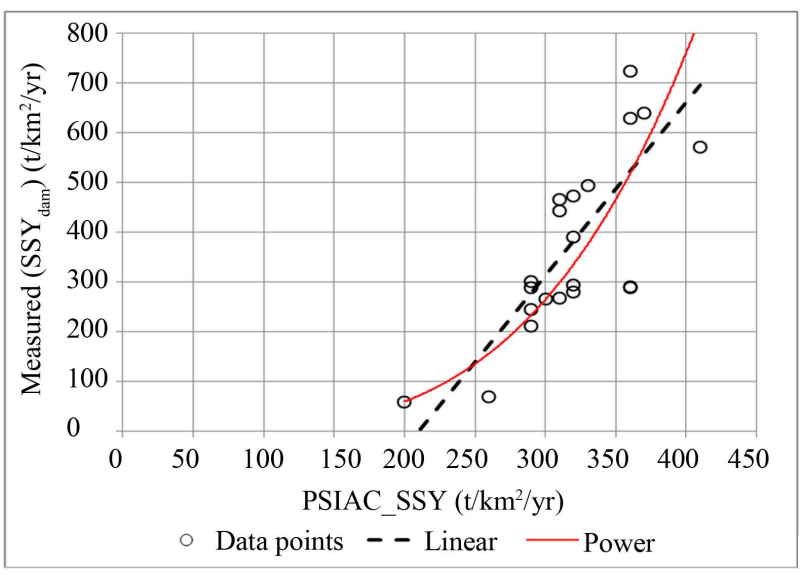

Figure 5. A scatter plot of measured and uncalibrated PSIAC based sediment yield data points plus fitted linear and power functions.

study. It can be seen from Figure 5 that the strength of correlation increases substantially from linear $\left(\mathrm{r}^{2}=0.64\right)$ to power $\left(r^{2}=0.73\right)$ functions.

The regression output as presented in the Table 7 has three main components: 1) Regression statistics table; 2) ANOVA table; and 3) Regression coefficients table. Therefore, regressively the coefficient $\left(\alpha=4.91 \times 10^{-7}\right)$ and exponent $(\beta=3.52)$ of the power function were determined with the overall goodness-of-fit measure, $r$ Square $\left(r^{2}\right)$ of 0.73 . The resulting relationship is presented in Equation (8).

$$
\mathrm{SSY}=4.91 \times 10^{-7} \times(\text { PSIAC_SSY })^{3.52}
$$

where, SSY and PSIAC_SSY are predicted and PSIAC based sediment yield, respectively, in $\mathrm{t} / \mathrm{km}^{2} / \mathrm{yr}$.

You will note from Figure 6 that the 45 degree line (1:1 line) nearly bisects the 22 scatter points of calibrated model predicted SSY against measured/observed sediment yield. Table 8 below further presents the performance of the model using five (5) indices (objective func- 
Table 7. Regression statistics for power function.

\begin{tabular}{|c|c|c|c|c|c|c|c|}
\hline \multicolumn{2}{|r|}{ Multiple r } & \multicolumn{6}{|l|}{0.85} \\
\hline \multicolumn{2}{|r|}{ r Square } & \multicolumn{6}{|l|}{0.73} \\
\hline \multicolumn{2}{|r|}{ Adjusted r Square } & \multicolumn{6}{|l|}{0.72} \\
\hline \multicolumn{2}{|r|}{ Standard Error } & \multicolumn{6}{|l|}{0.15} \\
\hline \multicolumn{2}{|r|}{ Observations } & \multicolumn{6}{|l|}{22} \\
\hline \multicolumn{8}{|c|}{ ANOVA } \\
\hline & & $d f$ & $S S$ & $M S$ & $F$ & \multicolumn{2}{|c|}{ Significance $F$} \\
\hline \multicolumn{2}{|r|}{ Regression } & 1 & 1.26 & 1.26 & 54.19 & \multicolumn{2}{|c|}{$4.11 \mathrm{E}-07$} \\
\hline \multicolumn{2}{|r|}{ Residual } & 20 & 0.46 & 0.02 & & & \\
\hline \multicolumn{2}{|r|}{ Total } & 21 & 1.73 & & & & \\
\hline & Coefficients & \multicolumn{2}{|c|}{ Standard Error } & t Stat & P-value & Lower 95\% & Upper $95 \%$ \\
\hline $\log \alpha$ & -6.31 & \multicolumn{2}{|c|}{1.20} & -5.26 & $3.79 \mathrm{E}-05$ & -8.81 & -3.81 \\
\hline$\beta$ & 3.52 & \multicolumn{2}{|c|}{0.48} & 7.36 & $4.11 \mathrm{E}-07$ & 2.53 & 4.52 \\
\hline
\end{tabular}

Table 8. Evaluated PSIAC model performance.

\begin{tabular}{|c|c|c|c|c|}
\hline \multirow{2}{*}{ Performance Indices } & \multicolumn{2}{|c|}{ Calibrated PSIAC Model } & \multirow{2}{*}{ Uncalibrated PSIAC Model } & \multirow{2}{*}{ [4] Model' } \\
\hline & Calibration & Validation & & \\
\hline No. of Data Points & 22 & 9 & 31 & 22 \\
\hline$r^{2}$ & 0.73 & 0.97 & 0.66 & 0.17 \\
\hline NSE (\%) & 59.90 & 68.50 & 19.70 & -32.01 \\
\hline RMSE & 0.46 & 0.50 & 0.56 & 0.59 \\
\hline RSR & 0.63 & 0.56 & 0.89 & 1.15 \\
\hline PBIAS (\%) & 7.88 & 18.12 & 16.50 & 20 \\
\hline
\end{tabular}

* Sediment yield estimates for moderate and dry climate of Tanzania [4].

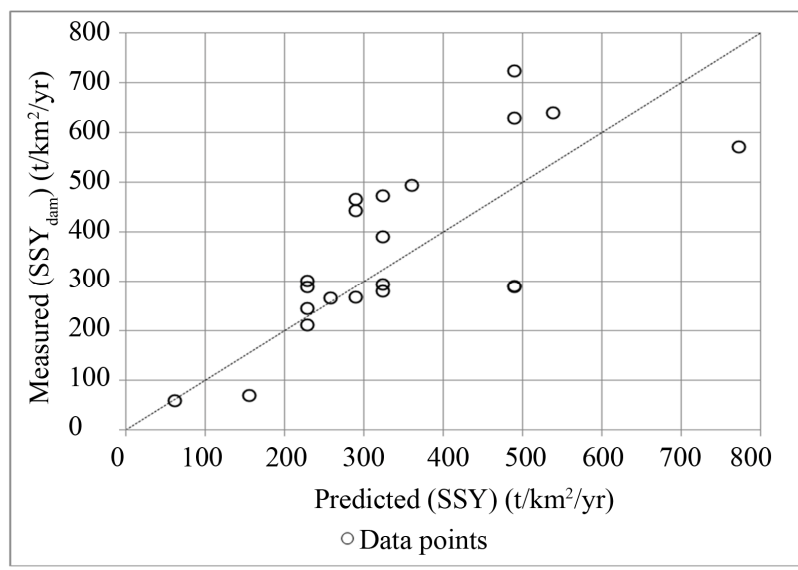

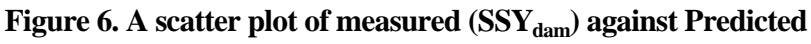
SSY data points using calibrated PSIAC model. tions), namely $\mathrm{r}^{2}$, NSE, RMSE, RSR and PBIAS. The model performance was reasonably good especially when evaluated against the PBIAS performance index.

The predicted catchments' sediment yields based on the calibrated and validated model as presented in Equation (8) vary from $61.76 \mathrm{t} / \mathrm{km}^{2} / \mathrm{yr}$ for Bulenya dam catchment to $772.82 \mathrm{t} / \mathrm{km}^{2} / \mathrm{yr}$ for Luperko dam catchment with an average of $358.29 \mathrm{t} / \mathrm{km}^{2} / \mathrm{yr}$ and coefficient of variation of $48.0 \%$. Generally the calibrated model performance was better than that of uncalibrated, though they were equally good in terms of PBIAS performance index (Table 8). Comparison with previously developed model by [4] in the same study area for moderate and dry climate indicates that the performance of the new model based on PSIAC concept has improved. These sediment yield estimates are comparable to the ones reported in [38], who 


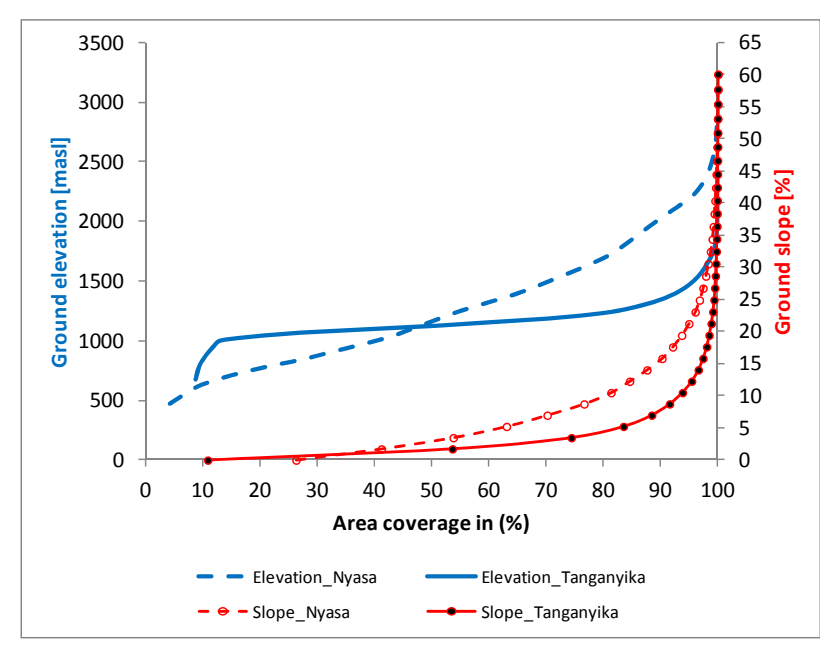

(a)

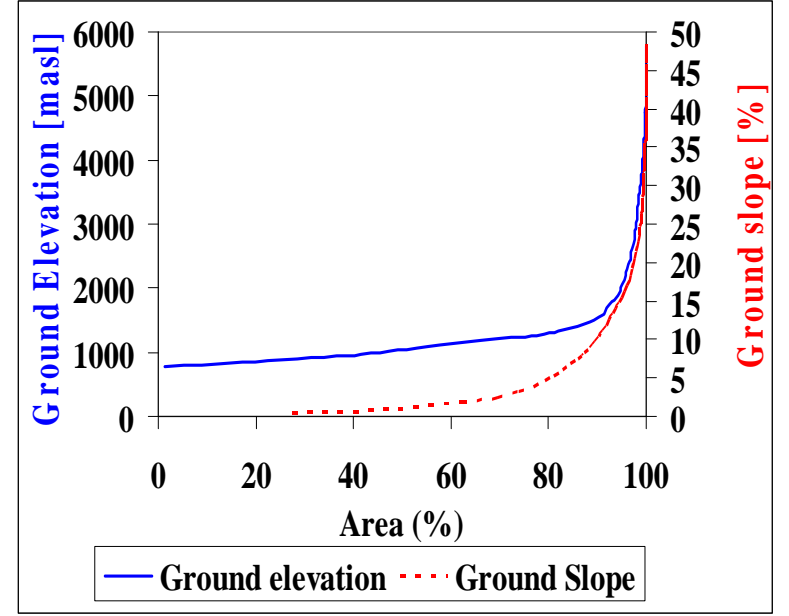

(b)

Figure 7. Distribution of ground elevation and slope with respect to area coverage in the 3 basins: Lake Nyasa, Lake Tanganyika and Pangani upstream of Nyumba Ya Mungu dam. (a) Lake Nyasa and Lake Tanganyika; (b) Pangani upstream of Nyumba Ya Mungu dam [5].

estimated sediment yields of $260-900 \mathrm{t} / \mathrm{km}^{2} / \mathrm{yr}$ or 2.6 - 9 $\mathrm{t} / \mathrm{ha} / \mathrm{yr}$. as averages for the longest periods of available records. The principal methods employed include field surveying and air photo interpretation.

\subsection{Extension of PSIAC Application to 3 Selected Large Basins of Tanzania}

As there were no readily available small dams siltation data in other regions, other than the central part of Tanzania, validation was made between uncalibrated PSIAC model sediment yields estimate and available published or report on sedimentation rates $[5,23,24]$ and catchment sediment yield rates [39]. In this exercise, PSIAC model used spot based field observations data to estimate sediment yield in three basins of Tanzania, viz., Lake Nyasa, Lake Tanganyika, and Pangani. It should be recalled that the performance of uncalibrated model in central part of Tanzania is presented in Table 8. Furthermore, as it was not possible to compare directly between the spot level and the regional based published sediment yields by [39], thus statistics such as mean and range were used instead (Table 9).

The mean value of $5.064 \mathrm{t} / \mathrm{ha} / \mathrm{yr}$ or $506.4 \mathrm{t} / \mathrm{km}^{2} / \mathrm{yr}$, for Lake Nyasa basin is enclosed in the range 5 to $7.5 \mathrm{t} / \mathrm{ha} / \mathrm{yr}$. or 500 to $750 \mathrm{t} / \mathrm{km}^{2} / \mathrm{yr}$. (Table 9). with some degree of confidence. Further validation of computed sediment yield results was done with respect to the observed Lake Nyasa sedimentation rate data as reported in [23]. Given the total area of $165,109 \mathrm{~km}^{2}$ for Lake Nyasa basin $\left(33,457 \mathrm{~km}^{2}\right.$ of water surface and $131,652 \mathrm{~km}^{2}$ of land area), the observed Lake Nyasa sediment deposition rate $(66,914,000 \mathrm{t} / \mathrm{yr})$ was determined as the product of lake area $\left(33,457 \mathrm{~km}^{2}\right)$ and sedimentation rate $(1 \mathrm{~mm} / \mathrm{yr}$ or $2000 \mathrm{t} / \mathrm{km}^{2} / \mathrm{yr}$ ) (Table 10). Simulated sediment yield rate of $54185850.31 \mathrm{t} / \mathrm{yr}$ from PSIAC approach is given by the product of Lake Nyasa basin on Tanzania side sediment yield rate $(16,105,280 \mathrm{t} / \mathrm{yr}$.) and total Lake Nyasa basin land area $\left(131,652 \mathrm{~km}^{2}\right)$ divided by Lake Nyasa basin on Tanzania side land area $\left(39,130 \mathrm{~km}^{2}\right)$. The Relative Error in percent, RE, of the estimate as computed using Equation (7) is therefore equal to $19 \%$. As the RE is below $20 \%$, the performance of the model in Lake Nyasa basin is acceptable for most technical practical problems.

You will also note that the mean sediment load of 6.5 $\mathrm{t} / \mathrm{ha} / \mathrm{yr}$. or $650 \mathrm{t} / \mathrm{km}^{2} / \mathrm{yr}$. for Lake Tanganyika basin is enclosed in the range 5 to $7.5 \mathrm{t} / \mathrm{ha} / \mathrm{yr}$. or 500 to 750 $\mathrm{t} / \mathrm{km}^{2} / \mathrm{yr}$. with some degree of confidence (Table 9). The sediment yield for the entire drainage basin using PSIAC model $(84,773,586 \mathrm{t} / \mathrm{yr}$.) was computed as the product of Lake Tanganyika basin on Tanzania side sediment yield rate $(57,402,746 \mathrm{t} / \mathrm{yr}$.) and total drainage area of Lake Tanganyika basin land area $\left(223,000 \mathrm{~km}^{2}\right)$ divided by land area of Lake Tanganyika basin on Tanzania side $\left(151,000 \mathrm{~km}^{2}\right)$.

The computed sediment yield results were compared with observed Lake Tanganyika sediment deposition rate data as reported in [24]. Lake Tanganyika sediment deposition rate estimated based on a sample of 7 variates published in [24] varies from 0.085 (offshore) to 1.2 $\mathrm{mm} / \mathrm{yr}$. (near shore). Based on the published data, this study, on statistical grounds, has computed an average sedimentation rate of $0.32 \mathrm{~mm} / \mathrm{yr}$. with confidence limits between 0.031 and 0.61 at $5 \%$ level of significance. The observed sedimentation rate $(20,864,000 \pm 18,908,000$ $\mathrm{t} / \mathrm{yr}$.) was estimated as the product of lake area $(32,600$ $\left.\mathrm{km}^{2}\right)$ and sediment deposition rate $(0.32 \pm 0.29 \mathrm{~mm} / \mathrm{yr}$ or $640 \pm 580 \mathrm{t} / \mathrm{km}^{2} / \mathrm{yr}$ ) (Table 10). Therefore, for the case of Lake Tanganyika basin, the relative error, RE, was much 
Table 9. Validation of computed PSIAC model sediment yield rates with published data by [39].

\begin{tabular}{ccccccc}
\hline \multirow{2}{*}{ Statistics } & \multicolumn{2}{c}{ Lake Nyasa Basin } & \multicolumn{2}{c}{ Lake Tanganyika Basin } & \multicolumn{2}{c}{ Pangani Basin } \\
\cline { 2 - 7 } & $\begin{array}{c}\text { Calibrated } \\
\text { PSIAC (t/ha/yr) }\end{array}$ & $\begin{array}{c}\text { Published Data } \\
\text { (t/ha/yr) }\end{array}$ & $\begin{array}{c}\text { Calibrated } \\
\text { PSIAC (t/ha/yr) }\end{array}$ & $\begin{array}{c}\text { Published } \\
\text { data(t/ha/yr) }\end{array}$ & $\begin{array}{c}\text { Calibrated } \\
\text { PSIAC (t/ha/yr) }\end{array}$ & $\begin{array}{c}\text { Published Data } \\
\text { (t/ha/yr) }\end{array}$ \\
\hline Mean & 5.064 & $5-7.5$ & 6.5 & $5-7.5$ & 5.05 & $2.5-5$ \\
Sample Variance & 3.605 & - & 8.580 & - & 9.918 & - \\
Confidence Level (95.0\%) & 0.767 & - & 2.095 & - & 2.633 & - \\
Standard Deviation & 1.899 & - & 2.929 & - & 1.113 & - \\
Standard Error & 0.372 & - & 0.926 & - & - & - \\
Field Points & 26 & - & 10 & - & & - \\
\hline
\end{tabular}

Table 10. Validation of computed PSIAC model sediment yield rates with published sedimentation rates by [5,23,24].

\begin{tabular}{|c|c|c|c|c|c|c|}
\hline & \multicolumn{2}{|c|}{ Lake Nyasa Basin } & \multicolumn{2}{|c|}{ Lake Tanganyika Basin } & \multicolumn{2}{|c|}{ Lake NYM in Pangani Basin } \\
\hline & $\begin{array}{l}\text { UnCalibrated } \\
\text { PSIAC }\end{array}$ & Published Data & $\begin{array}{l}\text { UnCalibrated } \\
\text { PSIAC }\end{array}$ & Published data & $\begin{array}{l}\text { UnCalibrated } \\
\text { PSIAC }\end{array}$ & $\begin{array}{c}\text { Published } \\
\text { Data }\end{array}$ \\
\hline Drainage Area $\left(\mathrm{km}^{2}\right)$ & \multicolumn{2}{|c|}{131,652} & \multicolumn{2}{|c|}{223,000} & \multicolumn{2}{|c|}{12,000} \\
\hline Lake Area $\left(\mathrm{km}^{2}\right)$ & \multicolumn{2}{|c|}{33,457} & \multicolumn{2}{|c|}{32,600} & \multicolumn{2}{|c|}{168} \\
\hline $\begin{array}{c}\text { Percent (\%) of Ground Area with Slope } \\
\text { Less than 3\% (Figure 7) }\end{array}$ & \multicolumn{2}{|c|}{54} & \multicolumn{2}{|c|}{74} & \multicolumn{2}{|c|}{73} \\
\hline Sedimentation Rate (mm/yr) & \multirow{2}{*}{\multicolumn{2}{|c|}{1}} & & $0.32 \pm 0.29$ & \multicolumn{2}{|c|}{ Not determined } \\
\hline Sedimentation Rate (Mt/yr) & & & 84.80 & $20.86 \pm 18.91$ & 5.99 & 0.411 \\
\hline Relative Error (\%) & \multicolumn{2}{|c|}{$19(<20)$} & \multicolumn{2}{|c|}{$>20$} & \multicolumn{2}{|c|}{$>20$} \\
\hline
\end{tabular}

greater than $20 \%$.

As presented in Table 9 the estimated mean sediment yield rate for Pangani basin is $5.05 \mathrm{t} / \mathrm{ha} / \mathrm{yr}$. or 505 $\mathrm{t} / \mathrm{km}^{2} / \mathrm{yr}$. with a standard deviation of $3.15 \mathrm{t} / \mathrm{ha} / \mathrm{yr}$. or 315 $\mathrm{t} / \mathrm{km}^{2} / \mathrm{yr}$. You will note that it is enclosed within a range of 2.5 to $0.5 \mathrm{t} / \mathrm{ha} / \mathrm{yr}$. or 250 to $500 \mathrm{t} / \mathrm{km}^{2} / \mathrm{yr}$. as published by [39] with some degree of confidence. It is worth noting that the mean annual sedimentation rate of 411,000 $\mathrm{t} / \mathrm{yr}$. at Nyumba Ya Mungu reservoir as reported in [5] is much less than the total sediment yield of 5.99 Million $\mathrm{t} / \mathrm{yr}$. as computed by PSIAC model for the $12,000 \mathrm{~km}^{2}$ NYM dam catchment area. Again, for the case of Pangani basin, the computed RE is greater than $20 \%$.

The foregoing discussions suggest that the PSIAC model did not perform well in terms of estimating furthermost downstream outlets in 2 large study basins. Independent analysis as supported by Figure 7 suggests that basin terrain characteristics might explain somewhat to the performance of the PSIAC model. For instance, one would note that about three-quarters of the Lake Tanganyika and Pangani upstream of Nyumba Ya Mungu dam basins are relatively flat with general ground slope of less than 3\% (Table 10 and Figure 7). That is to say, few meters increase in the ground height results into larger gain in area coverage. In the same basins, Figure 7 also depicts that about less than $20 \%$ of the area may be characterised as mild or steep slopes (i.e., ground slope of greater than 5\%). Another notable observation is that Lake Nyasa basin terrain is relatively much steeper with only half of the basin area characterized as flat land. With such terrain characteristics the PSIAC model performance was good. Only freely downloadable Digital Elevation Models $(\mathrm{DEM})$ of $1 \mathrm{~km} \times 1 \mathrm{~km}$ resolution were used to derive most of the morphological factors, but the author considers such result is comparable with the field observations in the basins. For instance, slopes greater than $40 \%$ and those less than $3 \%$ are typically found in the mountain slopes of Kilimanjaro and Malagarasi wetland flood plains in Pangani and Tanganyika basins, respectively. The discussion in this section suggests that there is a high chance for sediment eroded from upland catchments to be deposited before reaching the basin outlet as alluvium deposits. Therefore, these features were linked as major sediment depository sites in Lake Tanganyika basin as well as in the Pangani basin. As a result, much smaller proportion of upland eroded sediment reach the basin outlet of Pangani and Tanganyika with a poor model performance. Based on these results it is not apparent at this juncture whether the model performance is directly related to size of the drainage area, though for large basins the chances are high for sediment to redeposit before reaching the furthest outlet. 
In all these analyses, for the three large basins, it is considered by the author that the larger the validation sample size the better the results. PSIAC approach was considered giving meaningful estimates for our region, especially in small catchments and large basins with mild slope such as Lake Nyasa basin. However, the author would like to acknowledge a number of uncertainties in this study. For instance, error due to digitization and georeferencing of the scanned maps for runoff, rainfall, and surface geology were assumed minimal. The spatial grid size of 0.020 degrees used determines the resolution at which the data were captured/obtained from the digitized maps and could have affected the results. Accumulation of error might have also resulted from the conversion of input data presented in vector to vector form and/or raster formats processing. Besides, the author would like to note that the sedimentation rates as determined by previous studies $[5,23,24]$ may have some degree of uncertainty. As reported in literature, all techniques for estimating reservoir volume incorporate errors [1] and may range from about $\pm 10 \%$ to $30 \%$. Therefore, the rates computed above were considered allowable as it is within the uncertainty range of Lake or sediment volume estimates. However, for the case of Lake Tanganyika the error could be higher as sedimentation rate data collected were localized in the central part of the lake, near Kalya horst. So the data are spatially ill-representative as compared to data collected for Lake Nyasa by [23]. In particular, [24] admitted that certain limitations might arise when evaluating base level dynamics exclusively from core data. It should also be noted that the sediment yield estimates from Tanzania side of the basins for the cases of Nyasa and Tanganyika were transferred to the entire basin using specific sediment yield concept. In the latter approach, linearity was assumed. That is to say sediment yield contribution from all catchments around the lakes was assumed to be spatially constant.

\section{Conclusions and Recommendations}

The calibrated model was considered "good" $(\mathrm{NSE}=$ $60 \%$ and RSR $=0.63$ ), and coefficient of correlation (r) of 0.85 for set of data used for model fitting/calibration. PBIAS values were relatively low and considered "very good" for specific sediment yield prediction, ranging from $7.88 \%$ to $18.2 \%$. Besides, the performance of the uncalibrated model was equally good. These results demonstrate that PSIAC model can effectively estimate specific sediment yields in ungauged small catchments of Tanzania. The model might equally be extended to large basins with mild ground slopes. Thus, it can be a useful tool for evaluating potential sediment impacts within the study area to examine specific sediment yields.

The following specific recommendations are made from the experience gained through this study:

1) Because of the simplicity of the implemented empirical sediment model, Pacific Southwest Inter-Agency Committee (PSIAC), the present study estimated the model parameter indices on a qualitative basis. It is therefore recommended for future research to use a modified PSIAC model in order to estimate the parameters indices objectively. It was not possible during this study to apply it due to resources limitations in terms of spatial data requirements, time and personnel needed to estimate all PSIAC parameters using yet another model known as Bureau Land Management model.

2) Most of the dams data used, though few for model calibration and validation, were concentrated in the central part of Tanzania, hence further studies should use more data even beyond the central part of Tanzania.

3) It should be recalled that previous researchers elsewhere have indicated that this model performs better in small catchments with drainage areas size ranging between 0.05 and $86 \mathrm{~km}^{2}$. With spatial scale model application limitation, though indirectly investigated in this study with good performance in one of the 3 large basins of Tanzania, it is recommended to carry out rigorous study in future for the same purpose.

\section{Acknowledgements}

This work is part of the outputs of consultancy service in which the author as sedimentologist in a multidisplinary team charged by Ministry of Water with the responsibility of preparing an integrated Water Resources management and development plans for 3 basins in Tanzania, namely, Lake Nyasa, Lake Tanganyika and Pangani. I also appreciate the assistance rendered to me by my postgraduate and undergraduate students, viz. Mdee, O., Sechu, G., and Hamisi, A., in carrying out some geospatial data analysis. The paper was critically reviewed by Prof. Mtalo, F.W. and Dr. Kahimba, F. of University of Dar es Salaam and Sokoine University of Agriculture, respectively. Some recent data and information on small dams in Tanzania were provided by Ministry of Water senior staff, Dr. George Lugomela, the Assistant director department of Water resources and Mr. Nkuba, the head of dam safety unit. Finally, I'm indebted to the Directorate of Research of University of Dar es Salaam for covering paper preparation cost and publication fees.

\section{REFERENCES}

[1] G. L. Morris and J. Fan, "Reservoir Sedimentation Handbook," McGraw-Hill Book Co., New York, 1998.

[2] R. J. Garde and K. G. Ranga Raju, "Mechanics of Sediment Transportation and Alluvial Stream Problems," 
Third Edition, New Age International (P) Limited, Publishers, New Delhi, 2000, 5p.

[3] P. M. Ndomba, "Modeling of Sedimentation Upstream of Nyumba ya Mungu Reservoir in Pangani River Basin," Nile Basin Water Science and Engineering, Vol. 3, No. 2, 2010, pp. 25-38.

[4] P. M. Ndomba, "Developing Sediment Yield Equations for Small Catchments in Tanzania," In: D. Chen, Ed., Advances in Data, Methods, Models and Their Applications in Geoscience, InTech, China, 2011, pp. 241-260. www.intechopen.com

[5] P. M. Ndomba, "Modelling of Erosion Processes and Reservoir Sedimentation Upstream of Nyumba Ya Mungu Reservoir in the Pangani River Basin," Ph.D. Thesis, University of Dar es Salaam, Dar es Salaam, 2007.

[6] P. M. Ndomba and A. van Griensven, "Suitability of SWAT model in sediment yields modelling in the Eastern Africa," In D. Chen, Ed., Advances in Data, Methods, Models and Their Applications in Geoscience, InTech, China, 2011, pp. 261-284. www.intechopen.com

[7] J. G. Arnold, J. R. Williams and D. R. Maidment, "Continuous-Time Water and Sediment-Routing Model for Large Basins," Journal of Hydraulic Engineering, Vol. 121, No. 2, 1995, pp. 171-183. doi:10.1061/(ASCE)0733-9429(1995)121:2(171)

[8] A. van Griensven, P. Ndomba, S. Yalew and F. Kilonzo, "Critical Review of the Application of SWAT in the Upper Nile Basin Countries," Hydrology and Earth System Sciences, Vol. 16, No. 9, 2012, pp. 3371-3381. www.hydrol-earth-syst-sci.net/16/3371/2012/doi:10.5194 /hess-16-3371-2012 doi:10.5194/hess-16-3371-2012

[9] P. M. Ndomba, F. W. Mtalo and A. Killingtveit, "Model in Sediment Yield Modelling for Ungauged Catchments: A Case of Simiyu Subcatchment," EAWAG-Zurich, Zurich, 2005, pp. 61-69. www.brc.tamus.edu/swat

[10] M. K. Mulengera and R. W. Payton, "Estimating the USLE-Soil Erodibility Factor in Developing Tropical Countries," Tropical Agriculture, Vol. 76, No. 1, 1999, pp. 17-22.

[11] M. K. Mulengera, "Sediment Yield Predictionin Tanzania: Case Study of Dodoma District Catchments," Tanzania Journal of Engineering and Technology (TJET), Vol. 2, No. 1, 2008, pp. 63-71.

[12] P. M. Ndomba, F. W. Mtalo and A. Killingtveit, "Estimating Gully Erosion Contribution to Large Catchment Sediment Yield Rate in Tanzania," Journal of Physics and Chemistry of the Earth, Vol. 34, 2009, pp. 741-748. www.elsevier.com/locate/pce

[13] P. M. Ndomba, F. W. Mtalo and A. Killingtveit, "A Guided SWAT Model Application on Sediment Yield Modeling in Pangani River Basin: Lessons Learnt," Journal of Urban and Environmental Engineering, Vol. 2, No. 2, 2008, pp. 53-62. doi:10.4090/juee.2008.v2n2.053062

[14] P. Lawrence, A. Cascio, O. Goldsmith and C. L. Abott, "Sedimentation in Small Dams-Development of a Catchment Characterization and Sediment Yield Prediction Procedure," Department for International Development (DFID) Project R7391 HR Project MDSO533 by HR,
Department for International Development (DFID), Wallingford, 2004.

[15] P. Z. Yanda, "Temporal and Spatial Variations of Soil Degradation in Mwisanga Catchment, Kondoa, Tanzania," Ph.D. Dissertation, Stockholm University, Stockholm, 1995, 136p.

[16] PSIAC, Pasific Southwest InterAgency Committee, "Factors Affecting Sediment Yield in the Pasific Southwest Area and Selection and Evaluation of Measures for Reduction of Erosion and Sediment Yield," Report No. HY 12, Water Management Subcommitte on ASCE, Reston, 1998.

[17] RCD, Resource Conservation District, "PSIAC Model: Sediment Yields in Sub-watersheds of the Petaluma River," Resource Conservation District, Petaluma, 1998.

[18] J. V. Vogt, R. Colombo and F. Bertolo, "Driving Drainage Networks and Catchment Boundering. A New Methodology Combining Digital Elevation Data and Environmental Characteristics," Geomorphology, Vol. 53, No. 3-4, 2003, pp. 281-298. doi:10.1016/S0169-555X(02)00319-7

[19] P. Bazzoffi, G. Baldassarre and S. Vacca, "Validation of PSIAC Model for Automatic Assessment of Resservoir Sedimentation," In: M. Albertson, Ed., Proceedings of the International Conference on Reservoir Sedimentation, Colorado State University, Fort Collins, 1996, pp. 519528.

[20] R. Safamanesh, W. A. Sulaiman and M. F. Ramli, "Erosion Risk Assessment Using an Empirical model of Pasific Southwest Inter-Agency Committee Method for Zargeh watershed, Iran," Journal of Spatial Hydrology, Vol. 6, No. 2, 2006, pp. 105-120.

[21] L. Tamene, A. Abegaz, E. Aynekulu, K. Woldearegay and P. L. Vlek, "Estimating Sediment Yield Risk of Reservoirs in Northern Ethiopia Using Expert Knowledge and Semi-Quantitative Approaches," Lake and Reservoirs: Research and Management, Vol. 16, No. 4, 2011, pp. 293-305. doi:10.1111/j.1440-1770.2011.00489.x

[22] R. J. Last, A. A. Nyblade, C. A. Langston and T. J. Owens, "Crustal Structure of the East African Plateau from Receiver Functions and Raleigh Wave Phase Velocities," Journal of Geographical Research, Vol. 102, No. B11, 1997, pp. 24469-24483.

[23] C. H. Pilskaln and C. T. Johnson, "Seasonal Signals in Lake Malawi Sediments," Limnology and Oceanography, Vol. 36, No. 3, 1991, pp. 544-557.

[24] M. M. McGlue, K. E. Lezzar, A. S. Cohen, J. M. Russell, J. J. Tiercelin, A. A. Felton, E. Mbede and H. H. Nkotagu, "Seismic Records of Late Pleistocene Aridity in Lake Tanganyika, Tropical East Africa," Journal of Paleolimnology, Vol. 40, No. 2, 2007, pp. 635-653. doi:10.1007/s10933-007-9187-x

[25] GST, Geological Survey of Tanzania, "Geological Map of Tanganyika," 1959. www.gst.go.tz

[26] URT, United Republic of Tanzania, "Highway Design Manual Ministry of Works," 1999.

[27] SUA, Sokoine University of Agriculture, "Country Report: Tanzania, 'Managing Risk and Reducing Vulner- 
ability of Agricultural Systems under Variable and changing Climate'," Soli Water Management Research Programme, Sokoine University of Agriculture, Morogoro, 2007.

[28] N. Reynard, A. Andrews and N. Arnell, "The Derivation of a Runoff Grid for Southern Africa for Climate Change Impact Analyses," Regional Hydrology: Concepts and Models for Sustainable Water Resource Management, No. 246, IAHS Publication, Sheffield, 1997, pp. 23-30.

[29] L. R. Oldeman, R. A. Hakkeling and W. G. Sombroek, "Global Assessment of Soil Degradation (GLASOD): World Map of the Status of Human-Induced Soil Degradation," United Nations Environment Programme, International Soil Reference and Information Centre, 1991.

[30] M. Ilanloo, "Estimation of Soil Erosion Rates Using MPSIAC Models (Case Study Gamasiab Basin)," International Journal of Agriculture and Crop Sciences. Vol. 4, No. 16, 2012, pp. 1154-1158. www.ijagcs.com

[31] G. Gutman and A. Ignatov, "The Derivation of the Green Vegetation Fraction from NOAA/AVHRR Data for Use in Numerical Weather Prediction Models," International Journal of Remote Sensing, Vol. 19, No. 8, 1998, pp. 1533-1543. doi:10.1080/014311698215333

[32] NOAA, National Oceanic and Atmospheric Administration, "Normalized Difference Vegetation Index Map (NDVI)," 2013. http://www.ospo.noaa.gov/Products/land

[33] StatSoft, Inc., "Electronic Statistics Textbook (Electronic Version)," StatSoft, Inc., Tulsa, 2013. http://www.statsoft.com/textbook/

[34] D. N. Moriasi, J. G. Arnold, M. W. van Liew, R. L. Bingner, R. D. Harmel and T. L. Veith, "Model Evaluation Guidelines for Systematic Quantification of Accuracy in Watershed Simulations," American Society of $\mathrm{Ag}$ ricultural and Biological Engineers, Vol. 50, No. 3, 2007, pp. 885-900.

[35] J. E. Nash and J. V. Sutcliffe, "River Flow Forecasting through Conceptual Models: Part 1. A Discussion of Principles," Journal of Hydrology, Vol. 10, No. 3, 1970, pp. 282-290. doi:10.1016/0022-1694(70)90255-6

[36] H. L. Alder and E. B. Roessler, "Introduction to Probability and Statistics," 5th Edition, W.H. Freeman and Company, New York, 1972, 373p.

[37] C. G. Santhi, J. R. Arnold, W. A. Dugas, R. Srinivasan and L. M. Hauck, "Validation of the SWAT Model on a Large River Basin with Point and Nonpoint Sources," Journal of America Water Resources association, Vol. 37, No. 5, 2001, pp. 1169-1188. doi:10.1111/j.1752-1688.2001.tb03630.x

[38] C. Christiansson, "Soil Erosion and Sedimentation in Semi-Arid Tanzania: Studies of Environmental Change and Ecological Imbalance," Scandinavian Institute of African Studies, Uppsala, 1981, 208p.

[39] D. E. Walling and B. W. Webb, "Erosion and Sediment Yield: A Global Overview," Erosion and Sediment Yield: Global and Regional Perspectives, No. 236, IAHS Publication, Sheffield, 1996, pp. 3-19. 